\title{
Pemanfaatan sumber nitrogen organik dalam pembuatan nata de coco
}

Utilization of organic nitrogen sources in the manufacture of nata de coco

\author{
Budi Santosa $^{1 *}$, Rozana $^{2)}$, Astutik $^{3)}$ \\ ${ }^{1}$ Program Studi Teknologi Industri Pertanian, Universitas Tribhuwana Tunggadewi Malang \\ ${ }^{2}$ Program Studi Agroindustri Pangan, Politeknik Negeri Sambas \\ ${ }^{3}$ Program Studi Agroteknologi, Universitas Tribhuwana Tunggadewi Malang \\ *Email Korespondensi: budi.unitri@gmail.com
}

Informasi Artikel:

Dikirim: 20/08/2020; disetujui: 10/01/2021; diterbitkan: 30/03/2021

\begin{abstract}
In addition to requiring sugar as a carbon source, making nata de coco also requires a source of nitrogen to activate the extracellular enzymes of the Acetobacter xylinum bacteria in the manufacture of nata cellulose. Sources of nitogen used in the manufacture of nata de coco generally use inorganic nitrogen sources, which in their development have caused many pros and cons, especially with regard to food safety issues when this product is consumed as a beverage. This study aims to obtain the best alternative nitrogen source and concentration in making nata de coco. The experimental design used in this study was nested randomized design with 2 factors as the first factor, the type of nitrogen source, while the second factor was the concentration of the nitrogen source in the first factor. The types of nitrogen sources used as the first factor were tofu industrial wastewater, green bean sprouts and Azolla microphylla, while the second factor was the concentration of nitrogen sources consisting of 4 levels, namely $0.5 \%, 1 \%, 1.5 \%$ and $2 \%$. The parameters observed in this study were thickness of nata de coco, weight of nata de coco, crude fiber of nata de coco, number of Acetobacter xylinum cells in the nata de coco layer. The results showed that organic nitrogen sources (tofu, sprouts and Azolla microphylla liquid waste can be an alternative substitute for inorganic nitrogen sources (urea, ZA and ammonium sulfate) which have been commonly used in making nata. The highest quality nata de coco is produced from the treatment of organic nitrogen sources. sprouts with a concentration of $1.5 \%$ with a thickness of $2.83 \mathrm{~cm}$, a weight of 279.33 grams, a crude fiber content of $4.14 \%$ and the number of Acetobacter xylinum cells in the cellulose layer $0.4 \times 10^{7}$ cells $/ \mathrm{ml}$.
\end{abstract}

Key words: tofu liquid waste, sprouts, Azolla microphylla, nata de coco

\begin{abstract}
ABSTRAK
Pembuatan nata de coco selain memerlukan gula sebagai sumber karbon juga memerlukan sumber nitrogen untuk mengaktifkan enzim-enzim ekstraselular bakteri Acetobacter xylinum dalam pembuatan selulosa nata. Sumber nitrogen yang digunakan dalam pembuatan nata de coco umumnya menggunakan sumber nitrogen anorganik yang dalam perkembangannya banyak menimbulkan pro kontra terutama berkaitan dengan masalah keamanan pangan apabila produk ini dikonsumsi sebagai minuman. Penelitian ini bertujuan untuk mendapatkan sumber nitrogen alternatif dan konsentrasi terbaik dalam pembuatan nata de coco. Rancangan percobaan yang digunakan dalam penelitian ini Rancangan Acak Tersarang 2 faktor sebagai faktor pertamanya jenis
\end{abstract}


sumber nitrogen sedangkan faktor keduanya konsentrasi sumber nitrogen yang tersarang pada faktor pertama. Jenis sumber nitrogen yang digunakan sebagai faktor pertama berupa limbah cair industri tahu, kecambah kacang hijau dan Azolla microphylla sedangkan faktor keduanya yaitu konsentrasi sumber nitrogen yang terdiri atas 4 level yaitu $0,5 \%, 1 \%, 1,5 \%$ dan $2 \%$. Parameter yang diamati dalam penelitian ini ketebalan nata de coco, bobot nata de coco, serat kasar nata de coco, jumlah sel Acetobacter xylinum dalam lapisan nata de coco. Hasil penelitian menunjukkan sumber nitrogen organik (limbah cair tahu, kecambah dan Azolla microphylla dapat menjadi alternatif pengganti sumber nitrogen anorganik (urea, ZA dan ammonium sulfat) yang selama ini umum digunakan dalam pembuatan nata. Nata de coco kualitas paling tinggi dihasilkan dari perlakuan sumber nitrogen organik kecambah konsentrasi 1,5\% dengan ketebalan 2,83 cm, bobot 279,33 gram, kandungan serat kasar 4, 14\% dan jumlah sel Acetobacter xylinum di dalam lapisan selulosa nata $0,4 \times 10^{7} \mathrm{sel} / \mathrm{ml}$.

Kata kunci: limbah cair tahu, kecambah, Azolla microphylla, nata de coco

\section{PENDAHULUAN}

Nata de coco dibuat dengan cara fermentasi menggunakan bantuan bakteri Acetobacter xylinum dari bahan baku air kelapa (Santosa et al., 2012; Santosa et al., $2019^{\mathrm{a}}$ ). Kandungan paling besar di dalam nata setelah air yaitu serat dalam bentuk selulosa lebih dikenal dengan nama selulosa bakteri (Hidayat et al., 2006; Santosa et al., 2020a). Selulosa nata merupakan homopolimer yang tersusun atas molekul $\beta$-D-1,4 glukosa dengan ikatan $\beta$-glikosidik (Dayal et al., 2013; Ifadah et al., 2016; Lima et al., 2011; Santosa et al., 2020 ${ }^{\mathrm{b}}$ ). Kata nata berasal dari bahasa Spanyol yang berarti krim hasil fermentasi oleh Acetobacter xylinum ((Fifendy et al., 2011), sumber lain mengatakan nata berasal dari Filipina yang digunakan untuk menyebut produk pangan menyerupai agar-agar hasil fermentasi oleh Acetobacter xylinum (Hamad dan Andriyani, 2011).

Air kelapa dapat digunakan sebagai bahan baku dalam pembuatan nata de coco karena mengandung sumber karbon dan nitrogen (Santosa, 2020). Namun kandungan yang dimiliki air kelapa tersedia dalam jumlah kurang sehingga perlu ditambahkan dari luar agar tersedia dalam jumlah cukup untuk pertumbuhan Acetobacter xylinum

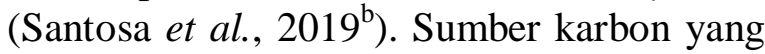
ditambahkan umumnya dalam bentuk sukrosa sedangkan sumber nitrogennya dalam bentuk urea, ZA atau amonium sulfat
(Hamad dan Kristiono, 2013; Ramadhan et al., 2019; Safitri et al., 2017; Wijayanti et al., 2016).

Acetobacter xylinum bisa bekerja dengan baik apabila dalam media mengandung karbohidrat, sumber nitrogen dan $\mathrm{pH}$ media harus asam. Karbohidrat diperlukan sebagai sumber karbon yang akan diubah menjadi selulosa oleh Acetobacter xylinum, sumber nitrogen) diperlukan untuk mengaktifkan enzim-enzim ekstraseluler bakteri Acetobacter xylinum sedangkan $\mathrm{pH}$ media dalam pembuatan nata harus asam karena Acetobacter xylinum termasuk dalam kelompok bakteri asam asetat sehingga bisa melakukan metabolisme dengan baik pada kondisi pH media asam (Lempang, 2013; Lestari et al., 2014; Pratiwi et al., 2012).

Produsen nata de coco selama ini dalam memproduksi nata menggunakan sumber nitrogen anorganik dalam bentuk pupuk urea atau ZA (ammonium sulfat) dengan alasan harganya murah dan mudah untuk mendapatkannya (Yanti et al., 2017). Dalam perkembangannya penggunaan sumber nitrogen anorganik seperti ini menjadi polemik di tengah-tengah masyarakat karena urea dan ZA merupakan pupuk yang aplikasinya bukan untuk makanan tetapi untuk tanaman selain itu pemakaian pupuk ini dikhawatirkan di dalam nata masih ada residu yang dapat menimbulkan penyakit apabila nata dikonsumsi (Hastuti et al., 2017). Hasil penelitian yang dilakukan Kholifah (2016) 
menyimpulkan bahwa di dalam nata mentah yang beredar di pasaran masih terdapat kandungan $\mathrm{Cu}, \mathrm{Zn}$ dan $\mathrm{Pb}$. Selain itu menurut Fifendy et al. (2011) penggunaan ammonium sulfat dengan konsentrasi yang tinggi dapat menurunkan $\mathrm{pH}$ media sehingga akan menghambat aktivitas Acetobacter xylinum karena $\mathrm{pH}$ terlalu asam. Pemerintah juga telah membuat peraturan melalui Peraturan Kepala Badan Pengawas Obat dan Makanan Republik Indonesia Nomor 7 Tahun 2015 tentang pelarangan penggunaan pupuk ZA sebagai bahan penolong dalam pembuatan nata de coco (Widyaningrum et al., 2016).

Permasalahan di atas perlu dicarikan solusi agar produsen nata dalam memproduksi tidak menemukan banyak masalah dan hambatan akibat pemakaian sumber nitrogen anorganik. Sumber nitrogen organik sebagai pengganti sumber nitrogen anorganik serta aman bagi kesehatan tubuh sebetulnya banyak tersedia di alam diantaranya limbah cair tahu, kecambah dan Azolla microphylla. Beberapa sumber (Azizah, 2017; Makiyah, 2013 dan Mubarak, 2007) menyebutkan kandungan nitrogen di dalam limbah cair tahu sebesar $697 \mathrm{ppm} / \mathrm{lt}$, kecambah 20 - 30\%/100 gram bahan dan Azolla microphylla 2 - 5\%/100 gram bahan. Kelebihan lain yang dimiliki oleh ketiga sumber nitrogen organik tersebut yaitu harganya murah dan cara mendapatkannya mudah. Penelitian Hastuti et al. (2017) menyimpulkan penggunaan ekstrak kecambah kacang hijau dapat meningkatkan ketebalan, bobot dan serat selulosa nata de lerry Berdasarkan uraian di atas diduga bahwa limbah cair tahu, kecambah dan Azolla microphylla dapat menggantikan sumber nitrogen anorganik yang selama ini dipakai oleh produsen nata. Penelitian ini bertujuan untuk mendapatkan jenis sumber nitrogen dan konsentrasi terbaik sebagai solusi untuk memecahkan permasalahan penggunaan nitrogen anorganik sebagai sumber nitrogen dalam pembuatan nata yang diragukan dari sisi keamanan pangan.

\section{METODE PELAKSANAAN}

\section{Bahan dan alat}

Bahan yang digunakan dalam penelitian ini air kelapa diambil dari buah kelapa varietas Mapanget (DMT) yang diperoleh dari kebun milik petani di Desa Dampit Kabupaten Malang. Bahan lain yang digunakan selain air kelapa yaitu kecambah kacang hijau yang diperoleh langsung dari produsen kecambah yang ada di kota Malang, limbah cair tahu yang diperoleh dari pabrik tahu yang ada di kota Malang, Azolla microphylla diperoleh dari petani yang membudidayakan Azolla, asam asetat glasial (merck) diperoleh dari toko kimia Makmur Sejati yang ada di kota Malang dan sukrosa merk gulaku diperoleh dari toko swalayan yang ada di kota Malang serta biakan murni Acetobacter xylinum diperoleh dari Laboratorium Mikrobiologi Universitas Brawijaya Malang.

Peralatan yang digunakan yaitu panci dari bahan stainless stell, bak fermentasi dengan spesifikasi dari bahan kaca transparan, ukuran bak panjang $11 \mathrm{~cm}$, lebar $11 \mathrm{~cm}$ dan tinggi bak $16 \mathrm{~cm}$, jangka sorong krisbow vernier caliper (KW0600071), gelas ukur kaca ukuran $100 \mathrm{ml}$ merk pyrex, timbangan analitik merk shimadzu, timbangan ukuran $100 \mathrm{~kg}$, spektrofotometri Vis (Visible), kuvetmerk UV-Vis, $\mathrm{pH}$ meter merk Hanna, pipet volume kaca ukuran 10 ml class A merk supertek,

\section{Pembiakan Acetobacter xylinum dalam Starter}

Penelitian ini diawali dari pembuatan starter, yang dimaksud starter yaitu strain Acetobacter xylinum dibiakkan ke dalam media. Pembuatan starter diawali dengan cara menginokulasikan strain murni ke dalam media air kelapa dari buah kelapa varietas Mapanget (DMT) yang sebelumnya sudah diperkaya diperkaya dengan nutrisi yaitu sukrosa dan ammonium sulfat dengan pH media asam (kisaran angka 4) dengan cara menambahkan asam asetat glasial. Jumlah sel Acetobacter xylinum yang diinokulasi ke dalam media air kelapa sejumlah $2 \times 10^{7} \mathrm{sel} / \mathrm{ml}$. Perhitungan jumlah 
sel dilakukan secara langsung menggunakan metode haemocytometer (Oliveira et al., 2015 dan Sulistyani et al., 2016)

\section{Pembuatan nata de coco}

Air kelapa darivarietas Mapanget (DMT) direbus pada suhu $100^{\circ} \mathrm{C}$ selama 15 menit. Kemudian ditambahkan sukrosa sebanyak $2 \%$ dan ammonium sulfat sejumlah 0,06\% selanjutnya dididihkan lagi. Media kemudian dituang ke dalam bak fermentasi dan ditutup kertas perkamen dan dilapisi kain saring selanjutnya diikat menggunakan karet gelang.

Media didinginkan selama 12 jam setelah itu $\mathrm{pH}$ media dibuat menjadi 4 dengan menambahkan asam asetat glasial sebanyak $20 \mathrm{ml}$. Langkah terakhir starter Acetobacter xylinum diinokulasikan ke dalam media dan diinkubasi selama 14 hari.

\section{Rancangan percobaan}

Rancangan percobaan yang digunakan Rancangan Acak Tersarang (Nested) 2 faktor. Faktor pertama jenis sumber N terdiri atas 3 level yaitu N1 = limbah cair tahu, $\mathrm{N} 2=$ kecambah, $\mathrm{N} 3=$ Azolla microphylla. Faktor kedua konsentrasi sumber $\mathrm{N}$ terdiri atas 4 level yaitu $\mathrm{K} 1=$ $0,5 \%, \mathrm{~K} 2=1 \%, \mathrm{~K} 3=1,5 \%$ dan $\mathrm{K} 4=2 \%$. Faktor kedua tersarang pada faktor pertama, setiap perlakuan diulang sebanyak 3 kali, sehingga diperoleh 36 sampel.

\section{Pengamatan Nata de Coco}

Parameter pengamatan diamati pada hari ke 14 setelah pemanenan yaitu ketebalan nata (Hamad dan Kristiono, 2013), bobot nata (Gayathry, 2015), kadar serat total nata de coco (Barry and Cleary, 2014)

\section{Analisis data}

Data yang diperoleh selama penelitian dianalisis menggunakan Analisys of Variance (ANOVA). Apabila terdapat beda nyata maka dilakukan uji lanjut dengan uji Beda Nyata Terkecil (BNT) pada $\alpha=1 \%$ (Hanafiah, 2012; Kumalaningsih, 2012).

\section{HASIL DAN PEMBAHASAN}

\section{Kualitas nata de coco}

Sumber nitrogen dalam media fermentasi nata merupakan salah satu faktor penting sebagai nutrisi untuk pertumbuhan bakteri Acetobacter xylinum. Sumber nitrogen dapat berasal dari senyawa organik atau anorganik. Pemanfaatan senyawa organik sebagai sumber nitrogen belum banyak dilakukan. Nitrogen diperlukan untuk mengaktifkan enzim ekstraselular bakteri Acetobacter xylinum.

Pada penelitian ini dilakukan pengamatan terhadap parameter kualitas nata de coco yaitu ketebalan nata, bobot nata dan serat kasar nata. Hasil analisis ragam menunjukkan sumber nitrogen dengan konsentrasi yang berbeda berpengaruh nyata terhadap seluruh parameter pengamatan. Hal tersebut dapat dilihat pada tabel di bawah ini

Tabel 1. Pengaruh sumber nitrogen dan konsentrasi yang berbeda terhadap kualitas nata de coco yang dihasilkan

\begin{tabular}{lccc}
\hline \multicolumn{1}{c}{ Perlakuan } & Ketebalan $(\mathrm{cm})$ & Bobot Nata $(\mathrm{g})$ & Serat Kasar \\
\hline N1K1 (Limbah cair tahu 0,5\%) & $1,20 \mathrm{a}$ & $122,67 \mathrm{~b}$ & $2,08 \mathrm{c}$ \\
N1K2 (Limbah cair tahu 1,0\%) & $1,80 \mathrm{c}$ & $146,00 \mathrm{~d}$ & $2,57 \mathrm{~d}$ \\
N1K3 (Limbah cair tahu 1,5\%) & $1,97 \mathrm{c}$ & $151,67 \mathrm{e}$ & $2,91 \mathrm{ef}$ \\
N1K4 (Limbah cair tahu 2,0\%) & $2,23 \mathrm{de}$ & $161,33 \mathrm{f}$ & $3,11 \mathrm{f}$ \\
N2K1 (Kecambah 0,5\%) & $2,27 \mathrm{e}$ & $152,33 \mathrm{e}$ & $3,57 \mathrm{~g}$ \\
N2K2 (Kecambah 1,0\%) & $2,43 \mathrm{f}$ & $178,33 \mathrm{~g}$ & $3,72 \mathrm{~g}$ \\
N2K3 (Kecambah 1,5\%) & $2,83 \mathrm{~g}$ & $279,33 \mathrm{~h}$ & $4,14 \mathrm{~h}$ \\
N2K4 (Kecambah 2,0\%) & $2,13 \mathrm{~d}$ & $134,67 \mathrm{c}$ & $2,69 \mathrm{de}$ \\
N2K1 (Azolla microphylla 0,5\%) & $1,13 \mathrm{a}$ & $108,67 \mathrm{a}$ & $1,21 \mathrm{a}$ \\
N2K2 (Azolla microphylla 1,0\%) & $1,33 \mathrm{a}$ & $121,67 \mathrm{~b}$ & $1,57 \mathrm{~b}$ \\
N2K3 (Azolla microphylla 1,5\%) & $1,6 \mathrm{~b}$ & $131,33 \mathrm{c}$ & $1,86 \mathrm{bc}$ \\
N2K4 (Azolla microphylla 2,0\%) & $1,69 \mathrm{c}$ & $144,00 \mathrm{~d}$ & $2,09 \mathrm{c}$ \\
\hline
\end{tabular}

Keterangan: Angka-angka yang diikuti huruf yang sama pada kolom yang sama berarti tidak berbeda nyata pada taraf BNT $1 \%$ 
Dari tabel di atas ditunjukkan bahwa sumber nitrogen yang berasal dari kecambah dengan konsentrasi $1,5 \% \quad(\mathrm{~N} 2 \mathrm{~K} 3)$ menghasilkan nata de coco kualitas tertinggi yaitu ketebalan $2,83 \mathrm{~cm}$, bobot 279,33 gram dan kandungan serat kasar 7,14\%. Hal ini dikarenakan kandungan nitrogen di dalam kecambah cukup tinggi yaitu sebesar 20-30\% per 100 gram bahan (Azizah, 2017). Kandungan nitrogen yang tinggi dalam kecambah telah mampu memenuhi nutrisi yang diperlukan oleh Acetobacter xylinum dalam biosintesa selulosa. Nitrogen dalam kecambah juga berfungsi untuk mengaktifkan enzim-enzim ekstraseluler bakteri Acetobacter xylinum (Lempang, 2013). Ketersediaan nutrisi yang cukup bagi bakteri akan menyebabkan produksi nata berlangsung optimal (Santosa, 2020).

Ketebalan dan bobot nata merupakan hasil metabolisme bakteri Acetobacter xylinum dapat digunakan untuk mengamati kemampuan bakteri dalam mengkonversi nutrisi menjadi selulosa. Ketersediaan nutrisi yang cukup akan menjadikan aktivitas Acetobacter xylinum menjadi tinggi sehingga produksi nata optimal. Nata yang dihasilkan dari fermentasi Acetobacter xylinum dengan sumber nitrogen dari kecambah memberikan ketebalan dan bobot nata tertinggi dan hal ini menunjukkan sumber nitrogen dari kecambah telah mencukupi kebutuhan nutrisi bagi Acetobacter xylinum dalam proses fermentasi dan mampu mengaktifkan enzimenzim ekstraselular.

Serat kasar merupakan hasil perombakan gula pada medium fermentasi oleh aktivitas Acetobacter xylinum (Santosa et al., 2019 $)$. Mikroorganisme dalam mensintesa dan menghasilkan nata dengan ikatan selulosa yang kuat salah satunya bergantung pada jumlah sumber nitrogen yang cukup dalam medium. Kandungan nitrogen dalam kecambah menunjukkan telah mencukupi kebutuhan nitrogen bagi Acetobacter xylinum. Semakin tinggi ketebalan nata, kadar serat juga meningkat.

Sumber nitrogen organik lain yang digunakan pada penelitian ini adalah limbah cair tahu dan Azolla microphylla. Parameter ketebalan, bobot dan serat kasar nata de coco yang dihasilkan pada perlakuan sumber nitrogen dari limbah cair tahu dan Azolla microphylla rata-rata berada di bawah dan berbeda nyata dengan nata de coco yang dihasilkan pada perlakuan sumber nitrogen kecambah. Diketahui bahwa kandungan nitrogen di dalam limbah cair tahu sebesar 697 ppm/liter dan Azolla microphylla 2 $5 \%$ per 100 gram bahan. Hal ini berada di bawah kandungan nitrogen kecambah yaitu sebesar $20-30 \%$ per 100 gram bahan. Kandungan nitrogen yang rendah akan menyebabkan pertumbuhan bakteri lambat sehingga nata yang dihasilkan akan tipis. Jumlah nitrogen yang sesuai dalam media akan merangsang bakteri menghasilkan nata dengan ikatan selulosa yang kuat dan tidak mudah luruh (Prastyana, 2002).

Konsentrasi nitrogen dalam kecambah yang menghasilkan kualitas nata tertinggi adalah sebesar $1,5 \%$. Peningkatan konsentrasi nitrogen justru menurunkan kualitas nata yang dihasilkan. Hal ini dapat dilihat pada tabel di atas. Ditunjukkan sumber nitrogen konsentrasi $2 \%$, nata yang dihasilkan memiliki rata-rata di bawah sumber nitrogen konsentrasi 1,5\%. Nitrogen merupakan komponen penting yang dibutuhkan dalam biosintesis nata de coco. Kebutuhan ini akan maksimum pada jumlah tertentu sehingga keberadaan sisa nitrogen justru memberikan efek menurunkan nata yang dihasilkan (Budhiono et al., 1999; Edria et al., 2008). Hasil penelitian Liana et al. (2007) dan Patria et al. (2013) menunjukkan penambahan konsentrasi nitrogen dapat meningkatkan jumlah polisakarida yang terbentuk, tetapi konsentrasi terlalu tinggi mengakibatkan penurunan rendemen dan penurunan derajat putih pada nata de coco yang dihasilkan.

Hasil ini sesuai dengan penelitian Naufalin dan Wibowo (2003) bahwa penggunaan ekstrak kecambah berpengaruh nyata terhadap pembentukan selulosa dan ketebalan nata. Penelitian Fifendy et al. (2011) menyatakan ekstrak kecambah sebagai sumber nitrogen dapat menghasilkan mutu nata yang lebih baik bila dibandingkan 
dengan perlakuan tanpa penambahan sumber nitrogen dan penambahan urea.

\section{Jumlah sel Acetobacter xylinum dalam lapisan nata}

Terbentuknya nata melibatkan mikroba yaitu bakteri Acetobacter xylinum. Pertumbuhan Acetobacter xylinum bisa berjalan dengan baik pada suatu media dengan syarat nutrisi yang cukup yaitu sumber karbon dan nitrogen. Selama tahap pembentukan selulosa dalam fermentasi sebagian sel Acetobacter xylinum akan terjebak di dalam lapisan selulosa sehingga menyebabkan jumlah sel bakteri di dalam media fermentasi menurun. Pengaruh berbagai sumber $\mathrm{N}$ organik dengan konsentrasi berbeda dapat dilihat pada tabel di bawah ini

Tabel 2. Pengaruh berbagai sumber nitrogen organik dengan konsentrasi yang berbeda terhadap jumlah sel Acetobacter xylinum di dalam lapisan nata de coco

\begin{tabular}{lc}
\hline \multicolumn{1}{c}{ Perlakuan } & Jumlah sel (sel/ml) \\
\hline N1K1 (Limbah cair tahu 0,5\%) & $45 \times 10^{7}$ \\
N1K2 (Limbah cair tahu 1,0\%) & $38 \times 10^{7}$ \\
N1K3 (Limbah cair tahu 1,5\%) & $31 \times 10^{7}$ \\
N1K4 (Limbah cair tahu 2,0\%) & $22 \times 10^{7}$ \\
N2K1 (Kecambah 0,5\%) & $3,7 \times 10^{7}$ \\
N2K2 (Kecambah 1,0\%) & $3,1 \times 10^{7}$ \\
N2K3 (Kecambah 1,5\%) & $0,4 \times 10^{7}$ \\
N2K4 (Kecambah 2,0\%) & $13 \times 10^{7}$ \\
N2K1 (Azolla microphylla 0,5\%) & $93 \times 10^{7}$ \\
N2K2 (Azolla microphylla 1,0\%) & $83 \times 10^{7}$ \\
N2K3 (Azolla microphylla 1,5\%) & $61 \times 10^{7}$ \\
N2K4 (Azolla microphylla 2,0\%) & $52 \times 10^{7}$ \\
\hline
\end{tabular}

$\overline{\text { Keterangan : Angka-angka yang diikuti huruf yang sama pada kolom yang sama berarti tidak berbeda }}$ nyata pada taraf BNT $1 \%$

Tabel 2 menunjukkan jumlah sel terkecil di dalam lapisan nata terdapat pada perlakuan kecambah konsentrasi $1,5 \%$ yaitu sebesar $0,4 \times 10^{7} \mathrm{sel} / \mathrm{ml}$. Hal ini diduga kecambah yang memiliki kandungan $\mathrm{N}$ tinggi akan meningkatkan aktivitas enzim ekstraselular yang dimiliki oleh Acetobacter xylinum. Peningkatan aktivitas enzim akan meningkatkan aktivitas bakteri dalam melakukan metabolisme dan hal ini menyebabkan jumlah sel yang terjebak dalam lapisan nata menjadi kecil.

Secara umum selama proses pembentukan lapisan nata, sel bakteri akan terjebak dalam lapisan selulosa nata. Semakin banyak jumlah sel yang terjebak dalam lapisan nata menyebabkan ketebalan, bobot dan kandungan serat kasar menurun karena sel bakteri terjebak tidak bisa melakukan metabolisme dengan baik. Hal ini sesuai dengan pendapat Santosa (2020) yang mengatakan selama pembentukan lapisan nata, jumlah sel Acetobacter xylinum dalam media fermentasi menurun dikarenakan banyak sel bakteri yang terjebak di dalam lapisan selulosa nata.

\section{KESIMPULAN}

Sumber nitrogen organik dapat menghasilkan nata de coco yang berkualitas. Perlakuan terbaik adalah sumber nitrogen dari kecambah dengan konsentrasi 1,5\% yaitu ketebalan nata $2,80 \mathrm{~cm}, 27,339$ gram dan kandungan serat kasar $4,14 \%$ serta jumlah sel Acetobacter xylinum dalam lapisan selulosa nata sebesar $0,4 \times 10^{7} \mathrm{sel} / \mathrm{ml}$.

\section{DAFTAR PUSTAKA}

Azizah, H. (2017). Pengaruh pemberian molase dan air rebusan kecambah, kacang hijau (phaseolus radiatus l.) terhadap kualitas nata de kakao 
(Theobroma radiatus L.) [Tugas Akhir]. Fakultas Sains Dan Teknologi. Universitas Islam Negeri Maulana Malik Ibrahim Malang.

Budhiono, A., Rosidi, B., Taher, H., \& Iguchi, M. (1999). Kinetic aspects of bacterial cellulose formation in natade-coco culture system. Carbohydrate Polymers, 40(2), 137-143.

Dayal, M. S., Goswami, N., Sahai, A., Jain, V., Mathur, G., \& Mathur, A. (2013). Effect of media components on cell growth and bacterial cellulose production from Acetobacter aceti MTCC 2623. Carbohydrate polymers, 94(1), 12-16.

de Marco Lima, G., Sierakowski, M. R., Faria-Tischer, P. C. S., \& Tischer, C. A. (2011). Characterisation of bacterial cellulose partly acetylated by dimethylacetamide/ lithium chloride. Materials Science and Engineering: C, 31(2), 190-197.

Edria, D. Wibowo, M., \& Elvita, K. (2008). Pengaruh penambahan kadar gula dan kadar nitrogen terhadap ketebalan, tekstur dan warna nata de coco. Jurusan Ilmu dan Teknologi Pangan. IPB Bogor.

Fifendy, M., Hilda Putri, D., \& Maria, S. S. (2011). Pengaruh penambahan touge sebagai sumber nitrogen terhadap mutu nata de kakao. Sainstek: Jurnal Sains dan Teknologi, 3(2), 165-170.

Gayathry, G. (2015). Production of nata de coco-a natural dietary fibre product from mature coconut water using Gluconacetobacter xylinum (sju-1). International Journal of Food and Fermentation Technology, 5(2), 231-235.

Hamad, A., \& Kristiono, K. (2013). Pengaruh penambahan sumber nitrogen terhadap hasil fermentasi nata de coco. Majalah Ilmiah Momentum, 9(1), 62-65.

Hamad, A., Andriyani, N. A., Wibisono, H., \& Sutopo, H. (2011). Pengaruh penambahan sumber karbon terhadap kondisi fisik nata de coco. Techno
(Jurnal Fakultas Teknik, Universitas Muhammadiyah Purwokerto), 12(2), 74-77.

Hanafiah, K.A. (2012). Rancangan percobaan (teori dan aplikasi). Jakarta: Rajawali Press.

Hastuti, M., Andriyani, M., Wiedyastanto, A., Savitskaya, D., Gisyamadia, G., \& Margono, M. (2017). Pemanfaatan ekstrak kecambah kacang hijau sebagai sumber nitrogen alternatif dalam pembuatan nata de lerry. Prosiding SNST Fakultas Teknik, 1(1), 1-5.

Hidayat, N., Padaga, M. C., \& Suhartini, S. (2006). Mikrobiologi industri. Yogyakarta. Penerbit Andi.

Ifadah, R. A., Kusnadi, J., \& Wijayanti, S. D. (2015). Strain improvement acetobacter xylinum menggunakan ethyl methane sulfonate (ems) sebagai upaya peningkatan produksi selulosa bakteri. Jurnal Pangan dan Agroindustri, 4(1), 273-282.

Kholifah, S. (2010). Pengaruh penambahan $\mathrm{Za}$ dan gula terhadap karakteristik fisik, organoleptik dan kandungan logam nata de coco. Bogor: IPB.

Kumalaningsih, S. (2012). Metodologi penelitian (kupas tuntas cara mencapai tujuan). Malang: UB Press.

Lempang, M. (2013). Produksi nata fruticans dari nira nipah. Jurnal Penelitian Hasil Hutan, 31(2), 110-119.

Lestari, P., Elfrida, N., Suryani, A., \& Suryadi, Y. (2014). Study on the production of bacterial cellulose from Acetobacter xylinum using agrowaste. Jordan Journal of Biological Sciences Short Communication, 7(1), 75-80.

Liana, Y. W., Muis, M., \& Arinong, A. R. (2007). Analisa usaha pembuatan nata de coco dengan menggunakan sumber dan kandungan nitrogen yang berbeda. Jurnal Agrisistem, 3(2), 77-78.

Makiyah, M. (2013). Analisis kadar N, P dan $K$ pada pupuk cair limbah tahu dengan penambahan tanaman matahari meksiko (Thitonia diversivolia). Universitas Negeri Semarang. 
McCleary, B. V. (2014). Modification to AOAC official methods 2009.01 and 2011.25 to allow for minor overestimation of low molecular weight soluble dietary fiber in samples containing starch. Journal of AOAC International, 97(3), 896-901.

Mubarak, H. (2007). Aplikasi ekstrak azolla microphylla dalam sistem hidroponik dan pengaruhnya terhadap serapan hara serta hasil tanaman sawi (Brasicca juncea L.). Fakultas Pertanian. Universitas Jember.

Naufalin, R., \& Wibowo. (2003). Pengaruh penambahan sukrosa dan ekstrak kecambah pada kualitas nata de cassava. Jurnal Pembangunan Pedesaan, 3(3), 49-56.

Oliveira, P. M., Brosnan, B., Furey, A., Coffey, A., Zannini, E., \& Arendt, E. K. (2015). Lactic acid bacteria bioprotection applied to the malting process. Part I: Strain characterization and identification of antifungal compounds. Food Control, 51, 433443.

Patria, A., Muzaifa, M., \& Zurrahmah, Z. (2013). Pengaruh penambahan gula dan amonium sulfat terhadap kualitas nata de soya. Jurnal Teknologi dan Industri Pertanian Indonesia, 5(3), 1-5.

Prastyana, F. (2002). Pembuatan nata de aqua, tinjauan dari jenis dan konsentrasi sumber nitrogen (urea, NPK, Za). Universitas Brawijaya. Malang.

Pratiwi, A., Elfita, E., \& Aryawati, R. (2012). Pengaruh waktu fermentasi terhadap sifat fisik dan kimia pada pembuatan minuman kombucha dari rumput laut Sargasssum sp. Maspari Journal, 4(1), 131-136.

Ramadhan, B. R., Rangkuti, M. E., Safitri, S. I., Apriani, V., Raharjo, A. S., Titisgati, E. A., \& Afifah, D. N. (2019). Pengaruh penggunaan jenis sumber gula dan urea terhadap hasil fermentasi nata de pina. Journal of Nutrition College, 8(1), 49-52.
Safitri, M. P., Caronge, M. W., \& Kadirman, K. (2018). Pengaruh pemberian sumber nitrogen dan bibit bakteri acetobacter xylinum terhadap kualitas hasil nata de tala. Jurnal Pendidikan Teknologi Pertanian, 3(2), 95-106.

Santosa, B. (2020). Proses Pembuatan bubuk probiotik lactobacillus plantarum menggunakan filler bacterial cellulose. Fakultas Teknologi Pertanian. Universitas Brawijaya. Malang.

Santosa, B., Ahmadi, K., \& Taeque, D. (2012). Dextrin concentration and carboxy methyl cellulosa (cmc) in making of fiber-rich instant baverage from nata de coco. IEESE International Journal of Science and Technology, 1(1), 6-11.

Santosa, B., Tantalu, L., \& Sugiarti, U. (2019). Penambahan ekstrak kulit buah naga pada pengembangan produk nata de coco berantioksidan. Teknologi Pangan: Media Informasi Dan Komunikasi Ilmiah Teknologi Pertanian, 10(1), 1-8.

Santosa, B., Wignyanto, W., Hidayat, N., \& Sucipto, S. (2020). Optimization of $\mathrm{NaOH}$ concentration and trichloroacetic acid in bacterial carboxymethylation cellulose. Food Research, 4(3), 594-601.

Santosa, B., Wignyanto, W., Hidayat, N., \& Sucipto, S. (2020). The quality of nata de coco from sawarna and mapanget coconut varieties to the time of storing coconut water. Food Research, 4(4), 957-963..

Santosa, B., Wirawan, W., \& Muljawan, R. E. (2019). Pemanfaatan molase sebagai sumber karbon alternatif dalam pembuatan nata de coco. Teknologi Pangan: Media Informasi Dan Komunikasi Ilmiah Teknologi Pertanian, 10(2), 61-69. 
Sulistyani, H., Fujita, M., Miyakawa, H., \& Nakazawa, F. (2016). Effect of roselle calyx extract on in vitro viability and biofilm formation ability of oral pathogenic bacteria. Asian Pacific journal of tropical medicine, 9(2), 119124.

Widiyaningrum, P., Mustikaningtyas, D., \& Priyono, B. (2017). Evaluasi Sifat Fisik Nata De Coco dengan Ekstrak Kecambah sebagai Sumber Nitrogen. Prosiding Seminar Nasional Pendidikan, Sains dan Teknologi ISBN 978-602-61599-6-0.

Fakultas

Matematika dan Ilmu Pengetahuan Alam Universitas Muhammadiyah Semarang: $234-239$.
Wijayanti, E. Hastuti, U.S., \& Rohman, F. (2016). Pengaruh macam gula terhadap tebal dan berat nata dari jeruk pamelo (citrus maxima (burn.f.)) varietas nambangan. Prosiding Seminar Nasional II Tahun 2016, Kerjasama Program Studi Fakultas Keguruan Dan Ilmu Pendidikan Dengan Pusat Studi Lingkungan Dan Kependudukan Universitas Muhammadiyah Malang: 326 - 332 .

Yanti, N. A., Ahmad, S. W., Tryaswaty, D., \& Nurhana, A. (2017). Pengaruh penambahan gula dan nitrogen pada produksi nata de coco. BioWallacea: Jurnal Penelitian Biologi (Journal of Biological Research), 4(1), 541-546. 